\title{
KERAGAMAN GENETIK TANAMAN KARET (HEVEA BRASILIENSIS MUELL ARG.) DARI HASIL PERSILANGAN INTERSPESIFIK
}

\author{
Variability of Genetic Rubber Plant (Hevea brasiliensis Muell Arg.) \\ from Interspesific Crossing \\ Sekar WOELAN, SAYURANDI, dan Edy IRWANSYAH \\ ${ }^{1)}$ Pusat Penelitian Karet \\ Jalan Salak No 1 Bogor 16151 \\ Email : sekaryudi@yahoo.com \\ ${ }^{2)}$ Balai Penelitian Sungei Putih, Pusat Penelitian Karet \\ PO BOX 1415, Medan 20001 \\ Email : sayurandi_sp@yahoo.com \\ ${ }^{3)}$ Gabungan Pengusaha Karet Indonesia (GAPKINDO) Cabang Sumut \\ J1. Jend. Gatot Subroto Komplek Tomang Elok BI I 41/156 \\ Sei Kambing B, Medan Sunggal, Medan 20112
}

Diterima : 20 Maret 2014 / Direvisi : 30 Mei 2014 / Disetujui : 7 Juli 2014

\begin{abstract}
Indonesian genetic variability of rubber germplasm has been enriched by conserving of the clones from the IRRDB (International Rubber Research and Development Board) expedition in Amazon Dale, Brazil in 1981. Opportunity to get the new superior genotypes will be higher by using hybridization between RRIM 600 X PN 1546. The first stage in rubber breeding is to select the best genotypes in seedling evaluation trial (SET). The selection was done to mind parameter mainly production potential (latex and wood) and growth (girth, bark thickness), bark anatomy (number and diameter of latex vessel, number of rubber particles), latex physiology (plugging index, yield index, rate of latex flow, sucrose, inorganic phosphate, thiol, Dry Rubber Content). The result of genotypes segregant from RRIM $600 \times$ PN 1546 had quite high diversity, for variables of latex as well as timber production. Girth, bark thickness, number of latex vessel, production index and latex flow rate showed highly significant correlation with latex production. The relationship between the 12 components of production was indicated with a determination coefficient value $R^{2}$ of $92.7 \%$ while the remaining $27.0 \%$ of information was unknown. The components of latex production that had high direct effect to latex production were number of latex vessels (0.722), rubber particles (0.591), girth (0.588), and bark thickness (0.556). Based on path analysis and stepwise regression, it was known that number of latex vessel and number of rubber particles had greater direct effect and without of the effect of multicoloniarities. The determination coefficient value of that both characters were $R^{2}$ of $61.90 \%$. The genotypes selected based on latex yield were No. 18/G-518, No. 9/G-567, and No. 28/G-577. Based on rubber wood yield the
\end{abstract}

genotypes selected were No 17/G-669 (volume of wood branching free), No. 19/G-567, No. 20/G-441 (volume of canopy wood) dan No. 19/G-567, No. 20/G-441, No. 27/ G-514 (volume of totalwood).

Keywords: Hevea brasiliensis, genetic variability, multiple regression, selection

Abstrak
Variabilitas genetik plasma nutfah karet
di Indonesia telah diperkaya dengan melakukan
konservasi genotipe karet dari hasil ekspedisi
IRRDB (International Rubber Research and
Development Board) di sungei Amazone, Brasil
pada tahun 1981. Peluang untuk mendapatkan
genotipe unggul baru akan lebih besar dengan
menggunakan persilangan antara RRIM 600 X PN
1546. Tahapan awal dalam pemuliaan tanaman
karet adalah dengan memilih genotipe terbaik di
pengujian seedling evaluation trial (SET). Seleksi
genotipe dilakukan berdasarkan parameter
potensi produksi (lateks dan kayu), pertumbuhan
tanaman (lilit batang, ketebalan kulit), anatomi
kulit (jumlah dan diameter pembuluh lateks,
jumlah partikel karet), serta fisiologi lateks
(indeks penyumbatan, indeks produksi,
kecepatan aliran lateks, kadar karet kering,
sukrosa, tiol, fosfat). Hasil penelitian
menunjukkan bahwa genotipe hasil persilangan
klon RRIM 600 X PN 1546 menunjukkan
keragaman yang tinggi untuk produksi lateks
maupun produksi kayu. Karakter lilit batang,
tebal kulit, jumlah pembuluh lateks, indeks
produksi dan kecepatan aliran lateks
menunjukkan adanya korelasi yang sangat nyata
terhadap produksi lateks. Adanya hubungan


diantara 12 komponen produksi ditunjukkan dengan besaran nilai koefisien determinasi yaitu $\mathrm{R}^{2}=92,7 \%$ dan sisanya $27,0 \%$ informasinya belum diketahui. Komponen produksi yang mempunyai pengaruh langsung cukup tinggi terhadap produksi yaitu pembuluh lateks $(0,722)$, partikel karet $(0,591)$, lilit batang $(0,588)$ dan tebal kulit $(0,556)$. Berdasarkan analisis lintas dan regresi bertatar, diketahui bahwa jumlah partikel karet dan jumlah pembuluh lateks memiliki pengaruh langsung paling besar sekaligus bebas dari efek multikolinieritas. Hal ini mengindikasikan bahwa, kedua peubah itu secara parsial menunjukkan hubungan yang nyata terhadap produksi lateks. Nilai koefisien determinasinya kedua karakter tersebut sebesar $61,90 \%$. Genotipe terseleksi berdasarkan produksi lateks adalah No 18/G-518, No 9/G567, dan No 28/G-577. Berdasarkan produksi kayu ditemukan pada genotipe No 17/G-669 (volume kayu bebas cabang), No 19/G-567, No 20/G-441 (volume kayu kanopi) dan No 19/G567, No 20/G-441, No 27/G-514 (volume kayu total).

Kata kunci: Hevea brasiliensis, keragaman genetik, regresi berganda, seleksi

\section{PENDAHULUAN}

Kegiatan persilangan tanaman karet secara terus-menerus dilakukan untuk mendapatkan keragaman genetik baru. Keragaman yang cukup besar ini sangat dibutuhkan untuk mendapatkan materi genetik yang akan digunakan sebagai bahan pengujian pada tahapan pemuliaan selanjutnya.

Tahapan setelah perakitan genotipe unggul baru dari proses pemuliaan tanaman karet adalah seleksi turunan hasil persilangan pada Seedling Evaluation Trial (SET) (Tan, 1987). Kegiatan seleksi yaitu memilih keturunan tanaman yang mempunyai keunggulan karakteristik yang lebih baik dari kedua induknya. Karakterkarakter tersebut sangat ditentukan oleh genotipe yang ekpresinya dipengaruhi oleh faktor lingkungan. Seleksi genotipe akan lebih efektif apabila dilakukan terhadap populasi yang mempunyai keragaman genetik yang sangat luas. Peluang untuk mendapatkan keragaman genetik luas tidak mudah, karena menghadapi banyak tantangan yaitu rendahnya persentase buah jadi dan waktu yang dibutuhkan cukup lama. Disamping itu beberapa peneliti Wycherley (1969), dan Ho (1975) menyatakan bahwa, adanya ketidak terkaitan antara produksi dan sebagian karakter pertumbuhan.

Persilangan, seleksi, dan perbanyakan klon dari genotipe unggul merupakan tahapan awal yang sangat penting yang digunakan untuk perbaikan karakter seperti pertumbuhan, produksi, dan sifat-sifat sekunder (Simmonds, 1989). Produksi merupakan obyek yang paling dominan dalam program perbaikan genetik melalui persilangan. Produksi diukur sebagai berat karet kering per unit area per satuan waktu (Simmonds, 1989). Sedangkan karakteristik pertumbuhan di antaranya berhubungan dengan ketahanan terhadap angin, morfologi kulit, jumlah pembuluh lateks, dan ketahanan terhadap penyakit. Keempat karakter pertumbuhan tersebut mempunyai peranan yang sangat besar terhadap produksi suatu klon (Simmonds, 1989).

Evaluasi terhadap potensi produksi dapat dilakukan lebih awal dengan menggunakan penyadapan HMM (Hammarker Morris Man) selama 3 - 6 bulan dengan menggunakan sistem sadap $1 / 2 \mathrm{~S} \mathrm{~d} / 3$ pada ketinggian $50 \mathrm{~cm}$ di atas permukaan tanah (Mydin dan Mercykutty, 2007). Karakter pertumbuhan dievaluasi secara morfologi. Genotipe-genotipe yang terpilih berdasarkan produksi dan pertumbuhan 10\% terbaik akan digunakan sebagai materi Pengujian Pendahuluan dan 1\% terbaik sebagai materi Pengujian Plot Promosi.

Karakter agronomi suatu tanaman merupakan komponen yang menentukan besarnya produksi, sehingga perlu dikaji hubungan antar beberapa karakter dengan produksinya. Khusus untuk tanaman karet, pemuliaan tanaman tidak hanya bertujuan menghasilkan klon penghasil lateks saja tetapi juga diharapkan menghasilkan kayu yang tinggi. Pengkajian terhadap karakter agronomi seperti pertumbuhan tanaman (lilit batang, tebal kulit), anatomi kulit (jumlah pembuluh lateks, diameter pembuluh lateks, partikel karet), fisiologi lateks (sukrosa, fosfat anorganik, tiol, indeks penyumbatan, indeks produksi) dan hasil lateks perlu dikaji lebih mendalam. Korelasi diantara karakter tanaman merupakan dasar dalam program dan perencanaan pemuliaan yang lebih efisien. Tidak jarang dalam melakukan seleksi terhadap sifatsifat tertentu akan merubah sifat lainnya. 
Hal ini menunjukkan bahwa antara sifatsifat tersebut terdapat hubungan, baik secara positif maupun negatif. Berdasarkan beberapa hasil pecobaan dengan melihat komponen hasil, tidak ada varietas yang superior dalam semua sifat. Keunggulan yang dihasilkan merupakan hasil gabungan antara berbagai komponen hasil yang dapat diperoleh melalui persilangan dan setiap komponen hasil bersifat poligenik dalam keturunannya (Lasminingsih, 1993). Pola hubungan antara hasil dan komponen hasil dapat diketahui melalui perhitungan dengan menggunakan analisis korelasi, tetapi metode perhitungan menggunakan analisis korelasi ini memiliki kelemahan, karena dapat terjadi salah penafsiran yang disebabkan karena adanya saling interaksi antar komponen hasil. Pengaruh tak langsung melalui komponen lain dapat lebih berperan daripada pengaruh langsungnya. Selain itu hubungan kausal (sebab-akibat) tidak dapat dijelaskan dengan baik dengan metode ini. Kendala ini dapat diatasi dengan menggunakan analisis koefisien lintas (pathcoeficient analysis) yang mampu menentukan kontribusi relatif, dari komponen hasil terhadap hasil, baik secara langsung maupun secara tak langsung. Metode ini memecah koefisien korelasi antara masing-masing karakter yang dikorelasikan dengan hasil menjadi dua komponen, yaitu pengaruh langsung dan pengaruh tak langsung, sehingga hubungan kausal diantara karakter yang dikorelasikan dapat diketahui (Budiarti, 2004).

Paradigma baru bahwa tanaman karet tidak hanya menghasilkan lateks tetapi juga diharapkan kayu karetnya, maka seleksi juga diarahkan kepada klonklon yang berpotensi sebagai penghasil kayu. Sejak dari tahap awal seleksi sampai dengan pengujian klon, kedua peubah tersebut terus dievaluasi. Pada seleksi F1 yang merupakan tahap awal di dalam siklus pemuliaan tanaman karet, potensi genotipe penghasil lateks dan kayu menjadi fokus seleksi (Suhendry, 2002).

Berdasarkan uraian tersebut diatas maka diperlukan suatu pengkajian terhadap keragaman hasil persilangan interspesifik antara klon RRIM 600 x PN 1546. Tujuan dari penelitian ini yaitu : 1) mendapatkan data keragaman genotipe berdasarkan karakter pertumbuhan, fisiologi, anatomi kulit, produksi, 2) menyeleksi genotipe- genotipe yang mempunyai potensi sebagai penghasil lateks dan kayu dan 3) mendapatkan komponen produksi yang berkaitan langsung terhadap produksi lateks.

\section{BAHAN DAN METODE}

Penelitian ini dilakukan di Kebun Percobaan dan Laboratorium Balai Penelitian Sungei Putih-Pusat Penelitian Karet dan Laboratorium LIPI di Cibinong, pada bulan Januari 2009 sampai dengan Desember 2010. Bahan penelitian yang digunakan adalah genotipe (tanaman F1) hasil persilangan interspesifik dari klon RRIM 600 x PN 1546 sebanyak 25 genotipe dan 2 tetua (RRM 600 dan PN 1546). Bibit ditanam pada tahun 1998/1999 dengan jarak tanam $2 \times 2$ meter. Parameter yang diamati adalah: lilit batang, tebal kulit, jumlah dan diameter pembuluh lateks, produksi lateks, produksi kayu, kadar karet kering, indeks penyumbatan, indeks produksi, kadar sukrosa dan kadar fosfat anorganik lateks serta jumlah partikel karet.

Lilit batang, diukur pada ketinggian $50 \mathrm{~cm}$ di atas permukaan tanah dengan alat meteran kain (ukuran $100 \mathrm{~cm}$ ).

Tebal kulit, contoh kulit diambil dengan menggunakan alat pelobang kulit yang terbuat dari besi dengan diameter $1 \mathrm{~cm}$. Sedangkan alat yang digunakan untuk mengukur ketebalan kulit adalah caliper. Sampel kulit diambil di atas $5 \mathrm{~cm}$ dari sudut awal bidang sadap. Skala yang ditunjukkan oleh alat caliper dikalikan faktor koreksi sebesar 0,5 $\mathrm{mm}$.

Jumlah dan diameter pembuluh lateks, diukur menurut metode Gomez et al. (1972). Fiksasi contoh kulit dilakukan dengan larutan FAA (Formalin Acetic Acid). Pembuatan preparat semi permanen: kulit yang telah difiksasi dipindahkan dan dimasukkan ke dalam larutan $\mathrm{KOH}$ 15\% selama 1 jam, kemudian dibilas dengan akuades atau air mengalir selama 5 menit dan dikeringkan dengan kertas tisue. Selanjutnya direndam ke dalam larutan $\mathrm{HNO}_{3}$ selama 2 jam, dan dibilas lagi dengan air mengalir selama 5 menit dan dikeringkan dengan kertas tisue. Proses selanjutnya direndam dalam larutan alkohol 70\% selama 15 menit, dibilas kembali dengan akuades 
atau air mengalir dan dikeringkan dengan dihisap menggunakan kertas tisue agar tidak ada kandungan airnya, dan terakhir untuk dapat dilihat di bawah mikroskop diberikan pewarna Sudan III selama 30 menit. Kemudian preparat diiris dengan menggunakan pisau silet yang tajam secara membujur untuk melihat jumlah pembuluh, sedangkan untuk melihat diameter pembuluh lateks dipotong melintang. Masing-masing irisan tipis dari preparat tersebut diletakkan di gelas objek dan ditutup dengan gelas penutup (cover glass) yang sebelumnya diberikan gliserin untuk menjaga preparat itu tidak mengering. Setelah itu dilakukan pengamatan dibawah mikroskop dan diamati dengan pembesaran $40 \mathrm{x}$.

Produksi lateks, pengamatan potensi produksi masing-masing genotipe dilakukan dengan cara melakukan penyadapan pada tanaman seedling ( $\mathrm{F} 1$ ) dengan menggunakan pisau sadap biasa, pada ketinggian $50 \mathrm{~cm}$ di atas permukaan tanah yang dikenal dengan metode HMM (Hamarker Morris Man). Sistem penyadapan yang digunakan $1 / 2 \quad \mathrm{~S} d / 3$. Lateks ditampung dengan mangkok lateks, setiap kali penyadapan volume lateks yang dihasilkan diukur untuk mendapatkan potensi produksi masing-masing genotipe yang telah dihasilkan. Volume lateks yang dihasilkan kemudian ditimbang dengan menggunakan timbangan digital dan dibentuk dalam lum mangkok. Pengukuran karet kering yang telah dihasilkan yaitu dengan mengering anginkan di rumah kaca selama 3 minggu. Berat karet kering diukur dengan mengalikan berat lum dikalikan dengan faktor koreksi 0,85. Rata-rata potensi produksi dari masing-masing genotipe adalah jumlah lum selama 10 kali sadap per bulan.

Produksi kayu, potensi kayu yang dihasilkan dapat dihitung dengan pendekatan formula yang dikembangkan oleh Wan Razali Mohd et al. (1983) yaitu sebagai berikut:

$\mathrm{V} \mathrm{kbc}=\prod\left\{(\text { lilit batang } \mathrm{x} 0,01) / 2 \prod\right\}^{2} \mathrm{x}$ tinggi batang bebas cabang

Keterangan:

$\mathrm{Vkbc}=$ Volume kayu bebas cabang per pohon

$\Pi=3,142$

$\mathrm{Vp}=0,0435485+\{0,00005031 \times$ (lilit batang $\left./ \Pi)^{2}\right\} \times$ tinggi tanaman

Keterangan: $\mathrm{Vp}=$ Volume kayu per pohon
Kadar Karet Kering (KKK), diukur dengan beberapa tetes contoh lateks segar per unit percobaan diratakan pada gelas objek, ditimbang berat basahnya, kemudian dioven selama kurang lebih 2 × 24 jam dengan suhu sekitar $100^{\circ} \mathrm{C}$ sehingga bobotnya tidak berubah lagi. Nilai KKK adalah bobot kering dibagi dengan bobot basah, dan dikalikan dengan 100\%.

Indeks Penyumbatan (IP), pengamatan indeks penyumbatan (IP) dilakukan dengan metoda Milford et al. (1969) yaitu membandingkan volume lateks yang mengalir selama 5 menit yang pertama volume lateks yang dihasilkan dalam satu kali sadap. IP = Volume lateks yang mengalir 5 menit pertama/volume lateks yang dihasilkan dalam satu kali sadap x 100 .

Indeks Produksi (Ipr), pengukuran indeks produksi (IPr) dilakukan yaitu dengan mengukur rata-rata produksi (cc/p/s) dibagi lilit batang dikalikan 100\%.

Sukrosa, analisa terhadap sukrosa dilakukan dengan menggunakan metode anthron (Dische,1962). Pengukuran absorbansi turunan furfural setelah dehidrasi sukrosa dalam $\mathrm{H}_{2} \mathrm{SO}_{4}$ dan pemanasannya pada $627 \mathrm{~nm}$ dengan spektrofotometer Beckman DU 650.

Fospat anorganik, analisa terhadap Fospat anorganik (FA) dilakukan dengan menggunakan prinsip dasar pengikatan oleh amonium molibdat kemudian tereduksi oleh $\mathrm{FeSO}_{4}$ dalam reaksi asam sehingga menjadi warna biru yang kemudian diukur absorbannya pada $750 \mathrm{~nm}$ dengan spektrofotometer Beckman DU 650 (Taussky dan Shorr, 1953).

Jumlah partikel karet, untuk mengamati jumlah partikel karet dalam pembuluh kulit yaitu dengan pembuatan preparat contoh kulit segar diambil dengan ukuran $2 \mathrm{~cm} \times 1 \mathrm{~cm}$, kemudian direndam ke dalam larutan gluteraldehyde 3\% selama 2 jam dengan temperatur $4^{\circ} \mathrm{C}$, fiksasi dengan osmium $1 \%$ selama 2 jam dengan temperatur $4^{\circ} \mathrm{C}$, contoh kulit dilapisi dengan logam mulia (emas $24 \mathrm{~K}$ ), pengamatan jumlah partikel karet dilakukan dengan alat Scanning Electron Microscope Model S-430 Hitachi. Pembesaran yang digunakan yaitu $2850 \mathrm{x}$. 


\section{Analisis data segregasi dan seleksi genotipe hasil persilangan RRIM $600 \times$ PN 1546 berdasarkan produksi lateks dan kayu}

Secara umum telah diketahui bahwa klas fenotipe populasi semaian F1 menyebar secara normal, sehingga intensitas seleksi terhadap suatu sifat yang dipergunakan adalah areal yang terletak pada $10 \%$ dan $1 \%$ di sebelah kanan kurva normal. Pendugaan tersebut dilakukan dengan memanfaatkan rumus sebaran t sebagai berikut:

$$
t=\frac{X-\mu}{S d}
$$

$\mathrm{X}=$ Batas minimum parameter seleksi

$\mu=$ Rata-rata parameter populasi

$\mathrm{Sd}=$ Simpangan baku parameter

Hasil seleksi 10\% genotipe terbaik akan masuk dalam pengujian pendahuluan dan $1 \%$ genotipe terbaik masuk dalam pengujian plot promosi.

\section{Analisis sidik lintas komponen produksi lateks dengan produksi lateks}

Perhitungan analisis regresi digunakan untuk mengetahui besarnya pengaruh $\mathrm{X}$ terhadap $\mathrm{Y}$. Karakter yang diamati meliputi yaitu : $\mathrm{X}_{1}=$ lilit batang $(\mathrm{cm})$, $\mathrm{X}_{2}=$ tebal kulit $(\mathrm{mm}), \mathrm{X}_{3}=$ jumlah partikel karet (partikel), $X_{4}=$ jumlah pembuluh lateks (pembuluh), $\mathrm{X}_{5}=$ diameter pembuluh lateks $(\mu \mathrm{m}), X_{6}=$ indeks penyumbatan (\%), $X_{7}$ = indeks produksi (\%), $\mathrm{X}_{8}=$ kecepatan aliran lateks (cc/menit), $X_{9}=$ kadar tiol $(\mathrm{mM})$, $\mathrm{X}_{10}=$ kadar fosfat $(\mathrm{mM}), \mathrm{X}_{11}=$ kadar sukrosa $(\mathrm{mM})$ dan $\mathrm{X}_{12}=$ kadar karet kering $(\%)$

Persamaan regresi berganda antar variabel $\mathrm{Y}$ dan variabel $\mathrm{X}_{\mathrm{i}}$ yaitu sebagai berikut: $\mathrm{Y}=\mathrm{bo}+\mathrm{b}_{1} \mathrm{X}_{1}+\mathrm{b}_{2} \mathrm{X}_{2}+\ldots . .+\mathrm{b}_{\mathrm{n}} \mathrm{X}_{\mathrm{n}} \quad(\mathrm{Y}=$ produksi lateks c : $\mathrm{X}=$ peubah bebas ke-i, untuk $\mathrm{i}=1,2, \ldots \ldots \ldots ., \mathrm{p}:$ bo, $\mathrm{b}_{1}, \ldots, \mathrm{b}_{\mathrm{n}}=$ koefisien regresi).

Hubungan kausal berupa diagram lintas antara peubah bebas dengan peubah tak bebas untuk komponen hasil. Untuk menghitung analisis koefisien lintas untuk produksi lateks digunakan metode matriks seperti yang dikemukakan oleh Singh dan Caudhary (1977).
Melalui lima persamaan pada produksi lateks dapat dicari besarnya nilai $\mathrm{P}_{\mathrm{P}}$ dengan metode substitusi persamaan nilai aljabar, sedangkan nilai $r_{i j}$ dapat dicari dengan menggunakan rumus sebagai berikut :

$$
\mathrm{r}_{\mathrm{ij}}=\frac{\sum \mathrm{x}_{\mathrm{i}} \mathrm{y}_{\mathrm{i}}-\left(\sum \mathrm{x}_{\mathrm{i}}\right)\left(\sum \mathrm{y}_{\mathrm{i}}\right) / \mathrm{n}}{\sqrt{\left(\sum \mathrm{x}_{\mathrm{i}}^{2}-\left(\sum \mathrm{x}_{\mathrm{i}}\right)^{2} / \mathrm{n}\right)\left(\sum \mathrm{y}_{\mathrm{i}}^{2}-\left(\sum \mathrm{y}_{\mathrm{i}}\right)^{2} / \mathrm{n}\right.}}
$$

Penafsiran nilai $r_{i j}$ dapat juga dilakukan dengan menggunakan program aplikasi SPSS 16 sehingga diperoleh matrik korelasi. Untuk mendapatkan vektor $\mathrm{C}$ dapat digunakan.

Rumus sebagai berikut : $\underline{\mathrm{C}}=\mathrm{A} \cdot \mathrm{B}^{-1}$

\section{HASIL DAN PEMBAHASAN}

\section{Data keragaman genotipe berdasarkan karakter pertumbuhan, fisologi, anatomi kulit dan produksi}

Berdasarkan pengamatan data di lapang dari 16 parameter yang diamati (Tabel 1), 13 parameter diantaranya merupakan komponen produksi yang berhubungan dengan produksi lateks yaitu seperti karakter morfologi (lilit batang, tebal kulit), fisiologi (sukrosa, fosfat anorganik, tiol, indeks penyumbatan, indeks produksi, kecepatan aliran lateks), anatomi kulit (jumlah pembuluh lateks, diameter pembuluh lateks), produksi lateks, kadar karet kering. Sedangkan komponen yang berhubungan dengan produksi kayu yaitu seperti volume kayu bebas cabang, volume kayu kanopi dan volume kayu total.

Tabel 1 menunjukkan bahwa terdapat adanya keragaman yang cukup besar diantara parameter yang telah diamati. Keragaman tertinggi diketemukan pada parameter indeks produksi $(100,18 \%)$, volume kayu kanopi $(84,51 \%)$, produksi lateks yaitu mencapai $(83,46 \%)$, jumlah partikel karet $(65,63 \%)$, volume kayu bebas cabang $(62,97 \%)$, volume kayu total $(62,98 \%)$, lilit batang $(30,43 \%)$, fosfat anorganik $(24,76 \%)$, indeks penyumbatan $(21,95 \%)$, tiol $(20,98 \%)$ dan jumlah pembuluh lateks (20,45\%). Sedangkan untuk diameter pembuluh lateks dan kecepatan aliran lateks variasinya sangat kecil yaitu 4,99\% dan 8,20\%. Hal ini menunjukkan bahwa terjadi segregasi 
Tabel 1. Analisis statistik 16 parameter tanaman hasil persilangan RRIM 600 x PN 1546

Table 1. The statistic analyzed of 16 parameters from RRIM $600 \times P N 1546$ crossing result plant

\begin{tabular}{|c|c|c|c|c|c|}
\hline $\begin{array}{l}\text { Peubah } \\
\text { Variables }\end{array}$ & $\begin{array}{l}\text { Rerata } \\
\text { Avarage }\end{array}$ & $\begin{array}{l}\text { Minimum } \\
\text { Minimum }\end{array}$ & $\begin{array}{l}\text { Maksimum } \\
\text { Maximum }\end{array}$ & $\mathrm{Sd}$ & $\begin{array}{l}\mathrm{CV} \\
(\%)\end{array}$ \\
\hline $\begin{array}{l}\text { Lilit Batang/cm } \\
\text { (Girth) }\end{array}$ & 43,85 & 19,00 & 70,50 & 13,34 & 30,43 \\
\hline $\begin{array}{l}\text { Tebal Kulit/mm } \\
\text { (Barkthickness) } \\
\text { Jumlah Pembuluh }\end{array}$ & 6,96 & 4,50 & 8,00 & 1,05 & 15,09 \\
\hline $\begin{array}{l}\text { Lateks / pembuluh } \\
\text { (Number of latex vessel) }\end{array}$ & 5,74 & 4,00 & 8,00 & 1,17 & 20,45 \\
\hline $\begin{array}{l}\text { Diameter Pembuluh Lateks/ } / \mu \mathrm{m} \\
\text { (Diametre of lateks vessel) }\end{array}$ & 20,06 & 16,88 & 23,13 & 1,88 & 4,99 \\
\hline $\begin{array}{l}\text { Jumlah Partikel Karet/partikel } \\
\text { (Number of latex particle) }\end{array}$ & 6,58 & 0,80 & 18,60 & 4,32 & 65,63 \\
\hline $\begin{array}{l}\text { Kadar Sukrosa /mM } \\
\text { (Sucrosa) }\end{array}$ & 5,06 & 3,42 & 6,50 & 0,86 & 16,98 \\
\hline $\begin{array}{l}\text { Kadar Fosfat Anorganik/mM } \\
\text { (Inorganic Phosphat) }\end{array}$ & 7,22 & 4,57 & 10,98 & 1,79 & 24,76 \\
\hline $\begin{array}{l}\text { Kadar Tiol/mM } \\
\text { (Thiot) }\end{array}$ & 0,42 & 0,30 & 0,65 & 0,09 & 20,98 \\
\hline $\begin{array}{l}\text { Indeks Penyumbatan /\% } \\
\text { (Plugging Index) }\end{array}$ & 48,14 & 28,64 & 70,84 & 10,57 & 21,95 \\
\hline $\begin{array}{l}\text { Indeks Produksi /\% } \\
\text { (Index of yield) }\end{array}$ & 56,95 & 15,79 & 126,19 & 5,71 & 100,18 \\
\hline $\begin{array}{l}\text { Kecepatan Aliran Lateks /\% } \\
\text { (Latex flow rate) }\end{array}$ & 22,75 & 5,26 & 41,82 & 1,86 & 8,20 \\
\hline $\begin{array}{l}\text { Kadar Karet Kering (\%) } \\
\text { (Dry Rubber Content) }\end{array}$ & 54,55 & 38,67 & 71,30 & 6,22 & 11,40 \\
\hline $\begin{array}{l}\text { Produksi }(\mathrm{g} / \mathrm{p} / \mathrm{s}) \\
(\text { Yield })\end{array}$ & 5,14 & 0,51 & 15,59 & 4,18 & 83,46 \\
\hline $\begin{array}{l}\text { Volume Kayu Bebas Cabang } / \mathrm{m}^{3} \\
\text { (Volume of free branching wood) }\end{array}$ & 0,06 & 0,01 & 0,18 & 0,04 & 62,97 \\
\hline $\begin{array}{l}\text { Volume Kayu Kanopi/m³ } \\
\text { (Volume of canopy wood) }\end{array}$ & 0,10 & 0,04 & 0,35 & 0,08 & 84,51 \\
\hline $\begin{array}{l}\text { Volume Kayu Total } / \mathrm{m}^{3} \\
\text { (Volume of total wood) }\end{array}$ & 0,17 & 0,05 & 0,41 & 0,10 & 62,98 \\
\hline
\end{tabular}

diantara turunan yang dihasilkan dari persilangan tetua betina (RRIM 600) yang mempunyai karakter produksi lateks tinggi dan tetua jantan (PN 1546) dengan karakter pertumbuhannyajagur.

\section{Analisis sidik lintas komponen produksi lateks dengan produksi-lateks}

Adanya hubungan diantara komponen produksi lateks terhadap produksi lateks dapat dilihat dari nilai korelasi dan nilai regresi linearnya (Tabel 2). Berdasarkan hasil analisis korelasi, lilit batang, tebal kulit, jumlah pembuluh lateks, diameter pembuluh lateks, indeks produksi dan kecepatan aliran lateks menunjukkan pengaruh yang sangat nyata dan nilainya positif terhadap produksi lateks, hal ini sesuai dengan hasil penelitian Woelan dan Sayurandi (2008). Berdasarkan hasil penelitian Sethuraj et al. (1974), Ho (1975), Woelan dan Azwar (1990) juga mengemukakan adanya hubungan yang cukup significan untuk parameter tersebut di atas. Sedangkan hubungan produksi dengan indeks penyumbatan, kadar tiol, kadar fosfat anorganik dan kadar sukrosa mempunyai nilai negatif yang artinya bahwa produksi akan meningkat apabila peubahpeubah tersebut menunjukkan penurunan.

Dari Tabel 2 diketahui hubungan tingkat keeratan antar parameter 
komponen produksi lateks. Nilai $r$ yang paling tinggi ditemukan antara lilit batang dengan tebal kulit $(0,851)$, indeks produksi dengan kecepatan aliran lateks $(0,832)$, dan kecepatan aliran lateks dengan sukrosa ($0,410)$. Adanya hubungan nyata antar komponen produksi lateks mengindikasikan bahwa, produksi lateks untuk tanaman karet dipengaruhi oleh beberapa faktor. Faktor-faktor penentu produksi lateks perlu diketahui agar usaha perbaikan produksi lateks melalui perakitan varietas baru lebih terarah.

Pemilihan terhadap 12 karakter sebagai peubah bebas tersebut di atas menunjukkan adanya pengaruh terhadap produksi lateks, maka analisis dilanjutkan dengan analisis regresi dan menghasilkan persamaan regresi sebagai berikut:

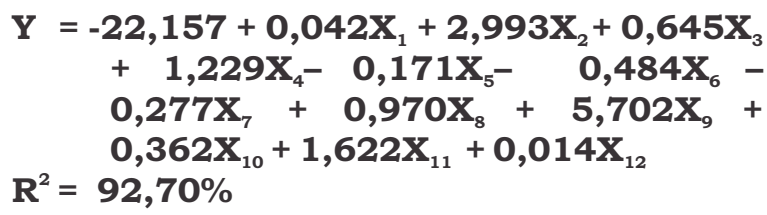

Persamaan regresi berganda di atas menunjukkan bahwa lilit batang $\left(\mathrm{X}_{1}\right)$, tebal kulit $\left(\mathrm{X}_{2}\right)$, jumlah partikel karet $\left(\mathrm{X}_{3}\right)$, jumlah pembuluh lateks $\left(\mathrm{X}_{4}\right)$, kecepatan aliran lateks
$\left(\mathrm{X}_{8}\right)$, kadar tiol $\left(\mathrm{X}_{9}\right)$, kadar fosfat anorganik $\left(\mathrm{X}_{10}\right)$, kadar sukrosa $\left(\mathrm{X}_{11}\right)$ dan kadar karet kering $(\mathrm{KKK}) \quad\left(\mathrm{X}_{12}\right)$ berpengaruh positif terhadap sifat daya hasil, sedangkan diameter pembuluh lateks, indeks penyumbatan $\left(\mathrm{X}_{6}\right)$, dan indeks produksi $\left(\mathrm{X}_{7}\right)$ berpengaruh negatif. Hal ini ditandai dengan variable-variabel bebas yang berpengaruh positif maupun negatif terhadap variabel $\mathrm{Y}$ (produksi lateks), yang mengindikasikan bahwa terjadi kolinearitas antara variabelvariabel tersebut di atas, yang ditunjukkan oleh koefisien determinasinya $\left(\mathrm{R}^{2}=92,7 \%\right)$. Ini berarti bahwa, masih ada sebesar $27,0 \%$ lagi informasi tentang produksi lateks yang belum dapat diterangkan dengan persamaan regresi tersebut. Adanya pengaruh positif berarti bahwa semakin besar nilai varibel tersebut maka diikuti semakin tinggi produksi lateks. Pengaruh negatif berarti menunjukkan bahwa semakin rendah nilai varibel tersebut maka semakin tinggi produksi lateks.

LB = Lilit Batang(Girth), TK = Tebal Kulit (Bark thickness), JPK = Jumlah Partikel Karet (Number of rubber particle), JPL = Jumlah Pembuluh Lateks (Number of latex vessels), DPL = Diameter Pembuluh Lateks (Diametre of latex vessel), IP = Indeks

Tabel 2. Koefisien korelasi antara komponen hasil lateks dengan hasil lateks Table 2. Coeffisient corelation between latex yield component with latex yield

\begin{tabular}{|c|c|c|c|c|c|c|c|c|c|c|c|c|c|}
\hline $\begin{array}{c}\text { Karakter } \\
\text { Characters } \\
\end{array}$ & $\begin{array}{l}\mathrm{LB} \\
(\mathrm{cm}) \\
\end{array}$ & $\begin{array}{c}\text { TK } \\
(\mathrm{mm})\end{array}$ & $\begin{array}{c}\text { JPK } \\
\text { (partikel) }\end{array}$ & $\begin{array}{c}\text { JPL } \\
\text { (pembuluh) }\end{array}$ & $\begin{array}{l}\text { DPL } \\
(\mathrm{m \mu})\end{array}$ & $\begin{array}{l}\text { IP } \\
(\%) \\
\end{array}$ & $\begin{array}{l}\text { Ipr } \\
(\%) \\
\end{array}$ & $\begin{array}{c}\text { KA } \\
\text { (cc/menit) }\end{array}$ & $\begin{array}{c}\text { Tiol } \\
\text { (mM) }\end{array}$ & $\begin{array}{c}\mathrm{Pi} \\
(\mathrm{mM})\end{array}$ & $\begin{array}{l}\text { Sukrs } \\
\text { (mM) }\end{array}$ & $\begin{array}{c}\text { KKK } \\
(\%)\end{array}$ & $\begin{array}{l}\text { PROD } \\
(\mathrm{g} / \mathrm{p} / \mathrm{s})\end{array}$ \\
\hline LB (cm) & - & $0,851^{* *}$ & 0,310 & 0,237 & 0,185 & $-0,105$ & 0,338 & 0,250 & $-0,334$ & $-0,253$ & $-0,005$ & $-0,211$ & $0,623^{* *}$ \\
\hline $\mathrm{TK}(\mathrm{mm})$ & & - & $-0,141$ & 0,152 & 0,166 & $-0,049$ & 0,372 & 0,288 & $-0,186$ & $-0,077$ & 0,040 & 0,123 & $0,082^{* *}$ \\
\hline JPK (partikel) & & & - & $-0,018$ & $-0,061$ & 0,319 & 0,082 & 0,250 & $-0,193$ & $-0,374$ & $-0,466$ & $-0,025$ & 0,070 \\
\hline JPL (pembuluh) & & & & - & $-0,176$ & $-0,358$ & 0,275 & 0,079 & $-0,174$ & 0,086 & 0,210 & 0,288 & $0,302^{* *}$ \\
\hline DPL $(\mathrm{m} \mu)$ & & & & & - & 0,158 & 0,170 & 0,321 & 0,132 & $-0,118$ & 0,183 & $-0,245$ & $0,243^{* *}$ \\
\hline IP (\%) & & & & & & - & $-0,359$ & 0,156 & $-0,104$ & $-0,005$ & $-0,266$ & $-0,231$ & $-0,171$ \\
\hline Ipr (\%) & & & & & & & - & $0,832^{* *}$ & $-0,142$ & $-0,210$ & $-0,172$ & $-0,228$ & 0,767 ** \\
\hline KA (cc/menit) & & & & & & & & - & $-0,242$ & $-0,199$ & $-0,410^{*}$ & 0,096 & $0,689^{* *}$ \\
\hline Tiol (mM) & & & & & & & & & - & 0,043 & $0,518^{* *}$ & $-0,186$ & $-0,254$ \\
\hline $\mathrm{Pi}(\mathrm{mM})$ & & & & & & & & & & - & 0,080 & 0,013 & $-0,168$ \\
\hline Sukr (mM) & & & & & & & & & & & - & 0,070 & $-0,129$ \\
\hline KKK (\%) & & & & & & & & & & & & - & 0,295 \\
\hline
\end{tabular}

Keterangan(Remaks):

** Berkorelasi nyata dengan uji t pada taraf 0,01 (Significantly correlation at $t$-test 0,01 )

Berkorelasi nyata dengan uji t pada taraf 0,0

(Significantly correlation at $t$-test 0,05 )

Penyumbatan (Plugging Index), IPr = Indeks Produksi (Index of yield), KA = Kecepatan Aliran lateks (Latex flow rate), $\mathrm{Pi}=$ Fosfat Anorganik (Inorganic phosphat), Sukrs = Sukrosa (Sucrosa), KKK = Kadar Karet Kering (Dry Rubber Content), PROD = Produksi (Yield).
Berdasarkan hasil analisis sidik lintas terhadap 12 karakter yang dipelajari diperoleh koefisien lintas yang menunjukkan adanya pengaruh langsung dan tidak langsung terhadap produksi lateks, seperti yang disajikan pada Tabel 3. 
Tabel 3. Hasil Analisis Lintas Untuk Komponen Hasil Lateks Dan Hasil Lateks

Table 3. The path analysis result for latex yield component and latex yield

\begin{tabular}{|c|c|c|c|c|c|c|c|c|c|c|c|c|c|c|}
\hline \multirow[t]{2}{*}{$\begin{array}{l}\text { Karakter } \\
\text { (Characters) }\end{array}$} & \multirow{2}{*}{$\begin{array}{l}\text { Pengaruh } \\
\text { langsung } \\
\text { (Direct } \\
\text { effect) }\end{array}$} & \multicolumn{12}{|c|}{$\begin{array}{c}\text { Pengaruh tidak langsung } \\
\text { (Indirect effect) }\end{array}$} & \multirow[t]{2}{*}{$\begin{array}{c}\text { Pengaruh total } \\
\text { (Total effect) }\end{array}$} \\
\hline & & $\begin{array}{l}\mathrm{LB} \\
(\mathrm{cm})\end{array}$ & $\begin{array}{c}\mathrm{TK} \\
(\mathrm{mm})\end{array}$ & $\begin{array}{c}\text { JPK } \\
\text { (partikel) }\end{array}$ & $\begin{array}{c}\text { JPL } \\
\text { (pembuluh) }\end{array}$ & $\begin{array}{l}\mathrm{DPL} \\
(\mathrm{m} \mu)\end{array}$ & $\begin{array}{l}\mathrm{IP} \\
(\%)\end{array}$ & $\begin{array}{l}\text { IPR } \\
(\%)\end{array}$ & $\begin{array}{c}\text { KA } \\
\text { (cc/menit) }\end{array}$ & $\begin{array}{c}\text { Tiol } \\
(\mathrm{mM})\end{array}$ & $\begin{array}{c}\text { PI } \\
(\mathrm{mM})\end{array}$ & $\begin{array}{l}\text { Sukr } \\
(\mathrm{mM})\end{array}$ & $\begin{array}{c}\text { KKK } \\
(\%)\end{array}$ & \\
\hline LB $(\mathrm{cm})$ & 0,588 & & -0.718 & $-0,349$ & $-0,001$ & $-0,294$ & 0,243 & 0,074 & 0,094 & 0,345 & 0,243 & 0,086 & $-0,181$ & $-0,553$ \\
\hline TK (mm) & 0,556 & $-0,095$ & - & 0,232 & $-0,201$ & 0,125 & $-0,268$ & $-0,176$ & 0,001 & $-0,147$ & $-0,229$ & $-0,137$ & 0,138 & $-0,670$ \\
\hline JPK (partikel) & 0,591 & $-0,008$ & 0,077 & - & $-0,428$ & 0,133 & $-0,012$ & 0,183 & -0.177 & -0.262 & 0,269 & 0,263 & 0,050 & 0,087 \\
\hline JPL (pembuluh) & 0,722 & $-0,009$ & $-0,238$ & $-0,088$ & - & 0,203 & 0,436 & 0,249 & $-0,275$ & 0,097 & $-0,251$ & $-0,245$ & $-0,055$ & $-0,186$ \\
\hline $\begin{array}{l}\mathrm{DPL} \\
(\mathrm{m} \mu)\end{array}$ & $-0,013$ & $-0,019$ & 0,116 & 0,021 & 0,116 & - & 0,182 & 0,311 & $-0,453$ & $-0,035$ & 0,045 & $-0,407$ & 0,312 & 0,212 \\
\hline IP (\%) & $-0,392$ & 0,004 & $-0,070$ & 0,001 & 0,071 & 0,023 & - & 0,831 & $-0,790$ & 0,169 & 0,146 & $-0,207$ & 0,022 & 0,197 \\
\hline IPR $(\%)$ & 0,161 & 0,001 & $-0,032$ & 0,006 & 0,028 & 0,027 & 0,020 & & $-0,943$ & 0,077 & 0,238 & $-0,278$ & $-0,027$ & $-0,880$ \\
\hline $\mathrm{KA}$ (cc/menit) & 0,110 & 0,004 & 0,001 & $-0,017$ & $-0,096$ & $-0,124$ & $-0,061$ & $-0,050$ & - & $-0,059$ & $-0,147$ & 0,406 & $-0,076$ & 0,235 \\
\hline Tiol (mM) & $-0,008$ & 0,458 & $-0,279$ & $-0,863$ & 0,114 & $-0,325$ & 0,442 & 0,138 & $-0,332$ & - & 0,007 & $-0,477$ & 0,177 & $-1,380$ \\
\hline PI (mM) & 0,012 & 0,018 & $-0,192$ & 0,039 & $-0,130$ & 0,018 & 0,017 & 0,019 & $-0,036$ & 0,057 & - & 0,039 & $-0,047$ & $-0,202$ \\
\hline Sukrs (mM) & $-0,008$ & 0,014 & $-0,323$ & 0,107 & $-0,357$ & $-0,464$ & $-0,207$ & $-0,278$ & 0,283 & $-0,112$ & 0,040 & - & $-0,047$ & $-1,361$ \\
\hline KKK (\%) & 0,165 & $-0,003$ & 0,033 & 0,002 & $-0,008$ & 0,036 & 0,001 & 0,001 & $-0,005$ & 0,420 & $-0,033$ & $-0,073$ & - & 0,371 \\
\hline
\end{tabular}

Pengaruh langsung lilit batang memberikan kontribusi positif dan besar $(0,588)$. Fakta ini didukung dari hasil koefisien korelasi yang sangat nyata dan positif $(r=0,623)$ yang artinya bahwa karakter tersebut dapat digunakan sebagai salah satu kriteria seleksi yang efektif untuk menduga hasil. Pengaruh tidak langsung lilit batang terhadap daya hasil melalui 6 karakter yang lain, yaitu seperti kadar tiol $(0,345)$, indeks penyumbatan $(0,243)$ dan fosfat anorganik $(0,243)$ adalah positif dan cukup besar. Sedangkan pengaruh tidak langsung melalui indeks produksi, kecepatan aliran lateks dan kadar sukrosa sangat kecil masing-masing 0,074; 0,094 dan 0,086. Pengaruh tidak langsungnya yang besar dan negatif melalui tebal kulit $(0,718)$, jumlah partikel karet $(0,349)$, dan diameter pembuluh lateks $(-0,294)$. Mengingat besarnya pengaruh langsung maupun koefiesien korelasi, maka karakter lilit batang dapat digunakan sebagai kriteria seleksi yang baik untuk mendapatkan genotipe baru yang mempunyai produksi lateks tinggi. Lilit batang merupakan salah satu komponen yang menentukan besarnya hasil, baik lateks maupun kayu (Woelan dan Sayurandi, 2008).

Karakter tebal kulit juga berkontribusi secara langsung dan positif terhadap produksi lateks sebesar 0,556. Hasil dari koefisien korelasi juga mendukung terhadap karakter tebal kulit yang ditunjukkan dengan nilai $r=0,682$. Karena itu karakter tebal kulit dapat digunakan sebagai kriteria seleksi yang baik untuk mendapatkan genotipe karet yang berpotensi produksi tinggi. Pengaruh tak langsung melalui karakter lain relatif kecil, sehingga mengakibatkan pengaruh total dalam sistem ini menjadi besar. Karakter tersebut baik digunakan untuk kriteria seleksi yang baik untuk menduga potensi produksi tinggi.

Karakter jumlah partikel karet memberikan kontribusi langsung yang nyata $(0,591)$ terhadap produksi lateks. Pengaruh tidak langsungnya besar dan nilainya positif melalui fosfat anorganik dan sukrosa. Hal ini dapat dipahami mengingat sukrosa dan fosfat anorganik berperan sebagai penyediaan energi anabolisme dan sintesis isoprena dalam sintesis partikel karet (Jacob et al., 1989; Tupy \& Resing, 1968; d'Auzac \& Pudarniscle, 1959 di dalam Sumarmadji, 1999).

Berdasarkan hasil penelitian Archer et al., 1969, McMullen \& McSweeney, 1966 di dalam Yusoff \& Chow (2003), partikel karet merupakan komponen yang esensial dalam biosintesis lateks. Dalam proses sintesis karet, partikel karet memerlukan molekul inisiator sebelum bergabung dengan IDP (Isopentenyl Diphosphate) ke dalam karet. Biosintesis karet Hevea merupakan hasil interaksi partikel karet dari seluruh lateks dan larutan $80 \mathrm{kDa}$ prenil trandsferase serum-C. Kunci modifikasi terhadap hal tersebut adalah protein 14,5 $\mathrm{kDa}$ sebagai protein pengikat membran partikel karet (Dennis dan Light, 1989 dalam Yusoff dan Chow, 2003).

Hasil analisis sidik lintas memperlihatkan bahwa jumlah pembuluh lateks mempunyai pengaruh langsung terhadap daya hasil yang sangat tinggi, 0,722 (Tabel 3). Fakta tersebut menunjukkan bahwa karakter jumlah saluran pembuluh lateks dapat digunakan 
sebagai kriteria seleksi yang efektif untuk menduga daya hasil produksi lateks. Hal ini juga didukung dengan nilai koefisien korelasi yang sangat nyata. Karakter jumlah saluran pembuluh lateks berkorelasi secara tidak langsung dan positif melalui diameter pembuluh lateks, indeks penyumbatan, indeks produksi. Sedangkan melalui sembilan karakter yang lain (lilit batang, tebal kulit, jumlah partikel karet, kecepatan aliran lateks, fosfat anorganik, sukrosa, Kadar Karet Kering) koefisien korelasi sidik lintasnya bersifat negatif, kecuali tiol dan relatif nilainya kecil.

Pembuluh lateks merupakan bioreaktor penghasil karet yang berbahan baku dari sukrosa yang berasal dari hasil fotosintesis. Pembuluh lateks tersusun secara vertikal dalam susunan cincin konsentrik yang saling menyambung antar pembuluh (anastomose) sehingga terbentuk seperti mantel. Sel pembuluh lateks dibentuk oleh meristem lateral (kambium) (de Fay dan Jacob, 1989 dalam Radith, 2009). Jumlah pembuluh lateks merupakan salah satu faktor yang menentukan produksi lateks. Hasil penelitian Hao dan Wu (2004) di dalam Novalina (2009) menyatakan bahwa diferensiasi sel pembuluh lateks kemungkinan diregulasi oleh asam jasmonat endogen.

Pengaruh langsung indeks penyumbatan terhadap produksi besar dan bersifat negatif. Pengaruh tidak langsungnya karakter indeks penyumbatan melalui indeks produksi dan kecepatan aliran lateks besar dan memberikan kontribusi lebih besar dibanding pengaruh langsungnya (Tabel 3). Hal ini membuktikan bahwa indeks penyumbatan berpengaruh tidak langsung terhadap produksi lateks melalui indeks produksi dan kecepatan aliran lateks. Namun demikian hasil analisis koefisien korelasi menunjukkan kedua karakter tersebut tidak berkorelasi.

Karakter indeks produksi berpengaruh besar dan bersifat negatif namun pengaruh langsungnya kecil, sehingga karakter-karakter yang berperan secara tidak langsung harus dipertimbangkan secara simultan dalam seleksi.

Karakter kecepatan aliran lateks pengaruh totalnya lebih besar dan pengaruh tidak langsungnya bernilai kecil. Berdasarkan pedoman analisis sidik lintas maka seleksi tidak langsung terhadap karakter tersebut akan efektif terhadap seleksi karakter utama, sebab pengaruh total tersebut menunjukkan hubungan yang sebenarnya (Wahyuni et al., 2004). Fenomena yang sama diperoleh dari hasil analisis regresi berganda yang menjelaskan hubungan antara karakter kecepatan aliran lateks dan produksi lateks. Aliran lateks ini sangat ditentukan oleh besarnya tekanan turgor, transfer air dari floem ke pembuluh lateks, dan proses koagulasi lateks (Jacob et al., 1989).

Kontribusi kadar karet kering memberikan fakta yang sama dengan karakter kecepatan aliran lateks, pengaruh totalnya lebih besar dan pengaruh tidak langsungnya bernilai kecil. Karena itu seleksi tidak langsung terhadap karakter tersebut akan efektif terhadap seleksi karakter utama.

Karakter diameter pembuluh lateks, tiol, fosfat anorganik dan sukrosa pengaruh langsungnya sangat kecil bahkan kurang dari 0,05. Hutagalung (1998), menyatakan bahwa koefisien lintas yang kurang dari 0,05 dapat diabaikan. Namun pengaruh totalnya besar, maka karakter-karakter yang berperan secara tidak langsung harus dipertimbangkan secara simultan dalam seleksi. Pengaruh tidak langsung karakter diameter pembuluh lateks yang besar melalui indeks produksi, kecepatan aliran lateks dan Kadar Karet Kering. Karakter tiol pengaruh tidak langsung yang nilainya besar melalui jumlah partikel karet, sukrosa, lilit batang, indeks penyumbatan dan kecepatan aliran lateks. Pengaruh tidak langsung karakter fosfat anorganik melalui beberapa karakter sangat kecil sekali $(<0,05)$ atau dapat diabaikan menurut Hutagalung (1998). Karakter sukrosa pengaruh tidak langsung yang nilainya besar melalui diameter pembuluh lateks, jumlah pembuluh lateks, tebal kulit dan kecepatan aliran lateks.

Berdasarkan analisis lintas dan regresi bertatar, diketahui bahwa jumlah partikel karet dan jumlah pembuluh lateks memiliki pengaruh langsung paling besar sekaligus bebas dari efek multikolinieritas (tidak saling mempengaruhi). Hal ini mengindikasikan bahwa, kedua peubah itu secara parsial menunjukkan hubungan yang nyata terhadap produksi lateks. 
Gambar 1 memperlihatkan hubungan kausal kedua peubah tersebut terhadap produksi lateks. Besarnya pengaruh langsung jumlah partikel karet menurun dari 0,591 menjadi 0,345, jumlah pembuluh lateks menurun dari 0,722 menjadi 0,575 , dan pengaruh sisa (model) meningkat dari 0,270 menjadi 0,617.

Hasil analisis regresi linear berganda kedua peubah itu terhadap produksi lateks menghasilkan persamaan $\mathrm{Y}=-16,675+$ $0,555 \mathrm{X}_{3}(\mathrm{JPK})+3,234 \mathrm{X}_{4}(\mathrm{JPL}) \quad\left(\mathrm{R}^{2}=0,619\right)$. Koefisien lintas $\mathrm{X}_{3}$ dan $\mathrm{X}_{4}$ pada Gambar 1 bila dibandingkan dengan koefisien regresi $\mathrm{X}_{3}$ dan $X_{4}$ dari persamaan di atas, menunjukkan adanya suatu kesesuaian. Hal ini dapat ditunjukkan dari besarnya nilai koefisien, dimana koefisien lintas $\mathrm{X}_{4}(0,575)$ lebih besar dari $\mathrm{X}_{3}(0,345)$, demikian halnya pada koefisien regresi $\mathrm{X}_{4}$ lebih besar dari $\mathrm{X}_{3}$. Hal ini memberikan indikasi bahwa, adanya tata hubungan yang sesungguhnya untuk kedua peubah tersebut dan mampu menjelaskan keragaman hasil lateks sebesar $61,9 \%$. Bila dilihat besarnya pengaruh langsung pada Tabel 4, maka jumlah pembuluh lateks dan jumlah partikel karet mempunyai nilai tertinggi. Peubah ini sangat sesuai digunakan untuk seleksi langsung genotipe yang mempunyai produksi lateks tinggi. Hasil penelitian Novalina (2009), mengemukakan karakter jumlah pembuluh lateks dan indeks penyumbatan pada populasi A (PB $260 \times$ PN 7111) memiliki pengaruh langsung paling besar ke produksi lateks. Karakter pembuluh lateks pengaruh langsungnya juga lebih tinggi $(0,519)$ dibanding indeks penyumbatan $(-0,408)$.

Mesquita et al. (2006) melaporkan bahwa, jumlah pembuluh lateks klon RRIM 600 (produksi tinggi) lebih tinggi dibanding GT1 (produksi sedang) dan FX 2261 (produksi rendah). Korelasi yang positif antara produksi lateks dan jumlah pembuluh lateks yang pertama dilaporkan oleh Bobilioff (1923) dalam Dikjman (1951).

Hasil penelitian Ginting (1985), menyatakan bahwa keragaman produksi tanaman karet umur 1,5 tahun di lapang rata-rata $79 \%$ dapat dijelaskan oleh jumlah partikel karet dalam pembuluh lateks. Berdasarkan dari persamaan regresi yang didapatkan mengindikasikan peningkatan produksi masing-masing kelompok klon berdasarkan produksi (tinggi, sedang, rendah) berhubungan langsung dengan jumlah partikel dalam pembuluh lateks (Gambar 2).

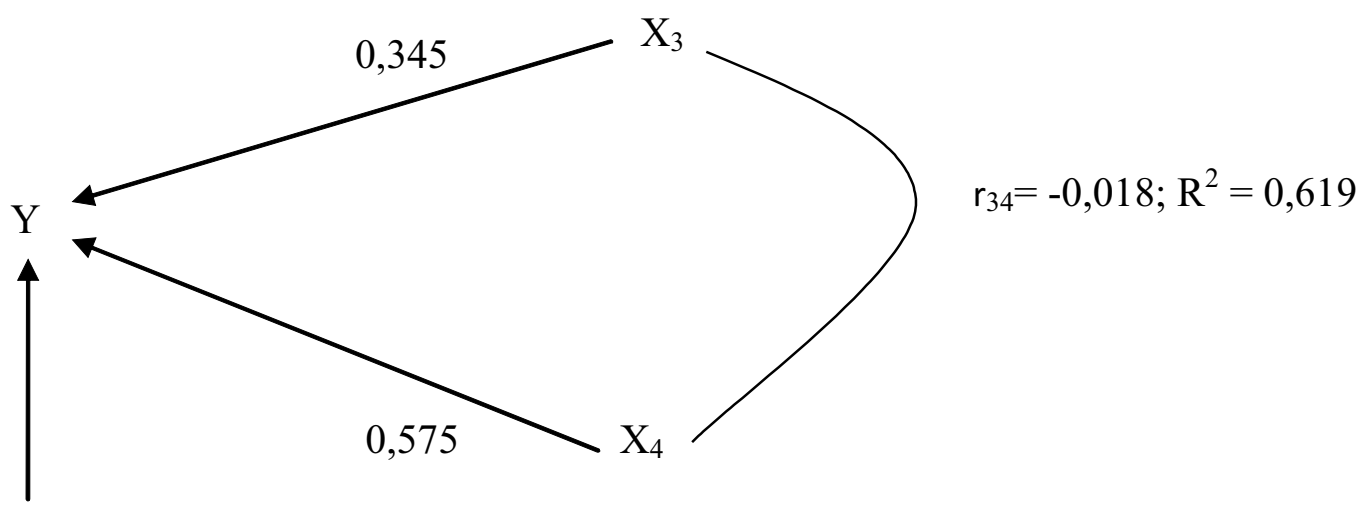

Gambar 1. Diagram lintasan hipotetik dari komponen jumlah partikel karet $\left(\mathrm{X}_{3}\right)$ dan jumlah pembuluh lateks $\left(\mathrm{X}_{4}\right)$ terhadap produksi $(\mathrm{Y})$

Figure 1. Diagram of hypothetical path from number of rubber particle $\left(X_{3}\right)$ and number oflatex vessel $\left(X_{4}\right)$ to yield $(Y)$ 


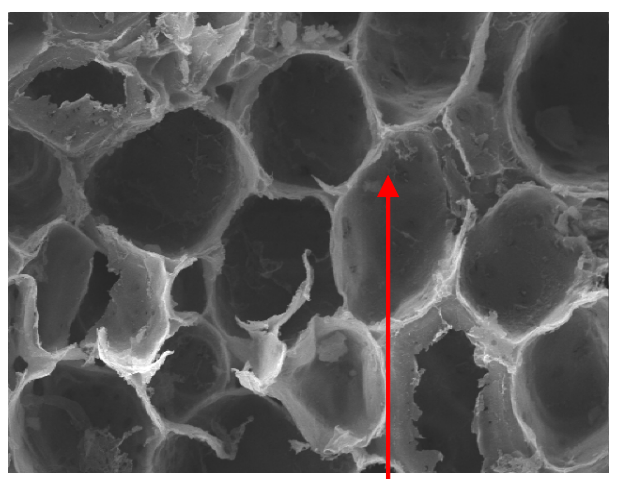

Saluran pembuluh lateks

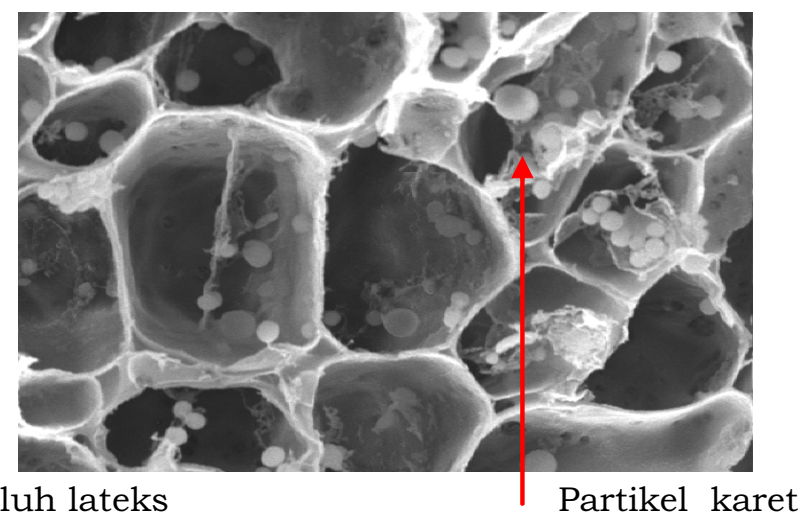

Partikel karet

Gambar 2. Pembuluh lateks dan partikel karet. Pengamatan menggunaka Scanning Electron Microscope (Model S-43 Hitachi). P. 2850 x

Figure 2. Latex vessel and rubber particle. Using observed by Scanning Electron Microscope (Model S-43 Hitachi). P. $2850 x$

\section{Seleksi Genotipe}

Seleksi individu dari hasil persilangan RRIM 600 x PN 1546 dilakukan terhadap individu-individu yang mempunyai keunggulan dari beberapa karakter dengan intensitas seleksi 10\%, 5\% dan 1\%. Beberapa individu yang terseleksi berdasarkan karakter morfologi (produksi, lilit batang, tebal kulit, volume kayu bebas cabang, volume kayu kanopi, volume kayu total), anatomi (jumlah partikel karet, jumlah pembuluh lateks, diameter pembuluh lateks) dan fisiologi (indeks penyumbatan, indeks produksi, kecepatan aliran lateks, kadar tiol, kadar fosfat anorganik, sukrosa, Kadar Karet Kering) dapat dilihat pada Tabel 4.

Individu-individu yang terseleksi berdasarkan masing-masing karakter dapat dilihat pada Lampiran 1. Disamping itu beberapa individu terseleksi berdasar atas beberapa karakter yang berbeda yaitu genotipe No 577 (produksi, diameter pembuluh lateks, indeks penyumbatan, kecepatan aliran lateks), No 518 (produksi, indeks produksi), No 567 (produksi, lilit batang, volume kayu karet, volume kayu total), No 442 (jumlah pembuluh lateks, Kadar Karet Kering), No 514 (jumlah pembuluh lateks, kadar sukrosa, volume kayu total), No 666 (diameter pembuluh lateks, kadar tiol, kadar fosfat anorganik, kadar sukrosa), No 669 (indeks penyumbatan, volume kayu bebas cabang), No 360 (kadar tiol, kadar fosfat anorganik) dan No 441 (lilit batang, volume kayu kanopi, volume kayu total).
Genotipe-genotipe yang terseleksi berdasarkan lebih dari satu karakter mengindikasikan bahwa genotipe tersebut berpeluang besar menjadi klon unggul baru. Tan (1989) menyatakan bahwa, produksi lateks yang utama sangat dipengaruhi oleh potensi genetik dari bahan tanam. Ekspresi potensi genetik tersebut berkaitan dengan faktor kejaguran tanaman dan ketebalan kulit yang merupakan karakter yang diturunkan, di samping faktor lingkungan dan manajemen kebun.

Turunan yang terseleksi dari persilangan interspesifik (RRIM 600 x PN 1546) menunjukkan bahwa, genotipe yang terseleksi adalah genotipe yang mempunyai keunggulan di atas rata-rata populasi. Besarnya keragaman yang dihasilkan dari masing-masing hasil persilangan memberikan indikasi bahwa, tanaman karet bersifat heterozygot.

\section{KESIMPULAN}

Keragaman yang tinggi ditemukan pada karakter indeks produksi, volume kayu kanopi, produksi, jumlah partikel karet, volume kayu total dan volume kayu bebas cabang. Sedangkan karakter diameter pembuluh lateks dan kecepatan aliran lateks keragamannya rendah.

- Genotipe terseleksi berdasarkan produksi lateks adalah No. 18/G-518, No. 19/G567 dan No. 28/G-577. Berdasrakan produksi kayu diketemukan pada projeni No. 17/G-669 (volume kayu bebas 
cabang), No. 19/G-567, No. 20/G-441 (volume kayu kanopi) dan No. 19/G-567, No. 20/G-441, no. 27/G-514 (volume kayu total).

( Kriteria seleksi yang efektif untuk menduga potensi produksi lateks adalah karakter lilit batang, tebal kulit, jumlah pembuluh lateks, jumlah partikel karet, indeks penyumbatan, indeks produksi dan kecepatan aliran lateks.

\section{DAFTAR PUSTAKA}

Budiarti, 2004. Analisis koefisien lintas beberapa sifat plasma nutfah gandum (Triticum aestivum L.) koleksi Balit Biogen. J. Pemuliaan Indonesia, 14(2): 31-40.

Dische, Z. M. 1962. Carbohydrate Chemical. Academic Press I: 488.

Gomez, J., R. Narayanan and K.T. Chen. 1972. Some structural factors affecting the productivity of Hevea brasiliensis Muell Arg.: I. Quantitative determination of the laticiferous tissue. J. Rubb. Res. Institute Malaya. 23 (3): 193-203.

Ho, C. Y. 1975. Clonal character determining the yield Hevea brasiliensis. Proceeding International Rubber Conference 1975. Kuala Lumpur. 2744p.

Ho, C. Y. 1976. Clonal character determining the yield of Hevea brasiliensis. Proc. Int. Rubb. Conf., Kuala Lumpur, 1975. 2, 17-38.

Lasminingsih, M. 1993. Analisis korelasi berbagai komponen karet sebagai bahan seleksi tanaman. J. Penelitian Karet, 13(1): 1-10.

Milford, G. F. J., E. C. Paardekooper., and C. V. Ho. 1969. Latex Vessel Plugging : Its Importance To Yield and Clonal Behavior. J. Rubb. Res. of Malaya 21 : 274-282.
Mydin, K.K and M. A. Mercykutty. 2007. High yield and precocity in RRII 400 series hybrid clones of rubber. Natural Rubber Research. 20 (1) : 39-49.

Sethuraj, M. R., S. Sulochanamma and P. J. George. 1974. Mapping SSR markers in rubber tree (Hevea brasiliensis) fasilited and enhanced by heteruduplex formation and template mixing. (Abstract). In (eds.): Bigwood B, Gale, M., Miksche, J. P., McChouch, S. (eds.) Scherago International. New York, USA. Plan Anim Genome V. Scherago International, California. 66 p.

Singh, R. K. and B. D. Chaudhary, 1977. Biometrical methods in quantitative genetic analysis. Haryana Agricultural University. New Delhi.

Simmonds, D. 1989. Rubber Breeding. In Webster C.C and Baukwill, WJ (Eds). Rubber. Longman Group, London. p. 85-124.

Suhendry, I. 2002. Klon karet unggul harapan penghasil lateks-kayu dari hasil pengujian pendahuluan. J. Penelitian karet, 20(1): 11-29.

Tan, H. 1987. Strategis in Rubber Tree Breeding, In: Cambel, A.I., Abbot, A. J. , Attein, R. K. (eds). Improvement of Vegetatively Propagated Plant. Academic Press. London. 44 p.

Wan Razali Mohd, Rosni Maidin, Ali Surjan and Johani Mohd Zain, 1983. Doubel entry volume table equation for source RRIM 600 series clone of rubber. The Malaysia Forester, 46 (1): 46-59.

Woelan, S. dan R. Azwar. 1990. Kompatibilitas Kombinasi Persilangan Dari Berbagai Klon Karet. Prosiding Lokakarya Pemuliaan Tanaman. Pontianak, 14-17 Juli 1990. Hal. 174189. 
Woelan, S. dan Sayurandi. 2008. Analisis sidik lintas komponen hasil latekskayu dan seleksi genotipe hasil persilangan di pengujian tanaman semaian. J. Penelitian Karet. 26 (2), 2008. $98-113$.
Wycherley, P. R. 1992. The Genus HeveaBotanical Aspects. Dalam: Sethuraj M. R., Mathew N. M., editor. Natural Rubber : Biology, Cultivation and Technology. Amsterdam : Elsevier. 